\title{
Local environmental NGO roles in biodiversity governance: a Czech-German comparison
}

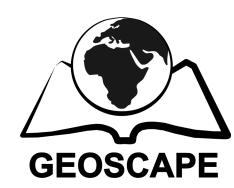

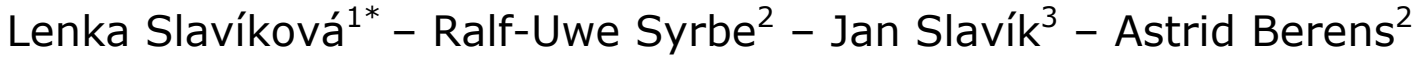 \\ ${ }^{1}$ Institute for Economic and Environmental Policy, J. E. Purkyně University \\ in Usti nad Labem, Czech Republic \\ *lenka.slavikova@ujep.cz \\ ${ }^{2}$ Leibniz Institute of Ecological and Regional Development (IOER), Dresden, Germany \\ ${ }^{3}$ Faculty of Social and Economic Studies, J. E. Purkyně University in Usti nad Labem, \\ Czech Republic
}

\begin{abstract}
Recently, the role of nongovernmental organizations (NGOs)s in environmental governance has been widely investigated, especially regarding the issue of mandatory public participation in policy-making within a European context. This paper aims to redirect scientific attention from their pure participation to their field actions, i.e., to the role they play in actual natural resource management, especially at the local level, and reframe local environmental NGO roles and positions based on the criteria for scale and influence. More specifically, this paper seeks to identify factors that promote NGOs as effective complements in the protection of state biodiversity and stresses local impacts of different governance schemes.

Determining factors were investigated through a series of in-depth case studies undertaken in the Czech-German border region of the eastern Krušné hory Mts. (Erzgebirge, Ore Mts.). Rather than a quantitatively oriented survey among NGOs, this study focused primarily on a specific territory and, subsequently, on the identification of relevant actor performance (including NGO representatives) within this territory. The method applied for comparison was the Institutional Analysis and Development Framework (IAD Framework). This design enabled a comparison of different social practices in the homogeneous ecosystem present on both sides of the border and captured the influence of specific social and historical cross-border features on environmental NGO performance.
\end{abstract}

Key words: biodiversity governance, environmental NGOs, IAD Framework, local scale, Eastern Krušné hory Mts.

\section{Highlights for public administration, management and planning:}

- Environmental NGOs may serve as effective complements of state biodiversity protection, especially when legally anchored in governance schemes and equipped with subsequent funding.

- Cooperation among different actors in a specific territory may create important synergies for reaching biodiversity governance goals.

- In territories where the socio-economic evolution has been strongly interrupted such as Sudetes) the lack of political acceptance is not compensated by civil society support of environmental NGOs. 


\section{Introduction}

NGOs (non-governmental organizations) are frequently defined as non-profit, voluntary, stateindependent organizations working for common welfare (Brüntrup-Seidemann 2011) or as voluntary entities gathering people with similar interests to promote those interests in public spaces (Spangenberg 2014). The purpose of their existence has been described in many ways - i.e., they exist to "develop community capacity to link with formal sector institutions" (Mac Abbey 2008 in Hedjazi \& Arabi 2009: 130) or to "compensate for the society imbalances emerging from the corporate domination of society" (Valentinov et al. 2015).

Recently, the role of NGOs in environmental governance has been widely investigated, especially regarding the issue of mandatory public participation in policy-making within a European context that is codified in e.g. in Water Framework Directive (see Niedzialkowski et al. 2012a; Cent et al. 2013; Koontz \& Newig 2014, among many others). In such situations, NGOs also serve as intermediaries between public officials and fragmented societies (CohenBlankshtain et al. 2013). The evaluation of their performance, however, is strongly dependent on the social context (e.g., post-totalitarian or democratic reality) and the scale (local, national, global) on which they operate. Whereas authors studying the role of NGOs in post-Communist countries stress the advantages of the abrupt development of a civil society and the increasing influence of NGOs (Carmin 2003; O'Brian 2011; Niedzialkowski et al. 2012b; Potluka \& Liddle 2014), others point out issues of accountability, legitimacy and transparency of public decisionmaking that may be threatened by excessive NGO participation (Newig \& Kvarda 2012; Spangenberg 2014). Some researchers view the very existence of NGOs as a government accountability deficit (Dombrowski 2010). Furthermore, the role of local NGOs deeply anchored in society structures is viewed differently than the role of large international entities (e.g., Wearing et al. 2005 with Becker \& Ghimire 2003; Nelson 2013 or Balboa 2014). Overall, the assessment of environmental NGO (hereafter referred to as
ENGOs) performance varies depending on various factors, as well as on different authors' perceptions.

This paper aims to redirect scientific attention from the pure participation of ENGOs in decisionmaking to their field actions, i.e., to the role they play in actual natural resource management, especially at the local level. We also do not presume to dictate what ENGOs should do, but rather, analyse what they actually do and why and how internal and external factors shape their actions. Our goal is to reframe the understanding of different ENGO situations based on criteria of scale and influence and to answer the following questions: How does an action of an ENGO in a certain territory shape biodiversity governance? What factors cause this action to complement, rather than compete with, state biodiversity protection?

The framing of ENGO roles and situations was developed based on a rigorous literature review. For Germany, an essential basis was the analysis of voluntary and private nature protection measures in Saxony (Wende et al. 2011). Determining factors were investigated through a series of in-depth case studies undertaken in the Czech-German border region of the Krušné hory Mts. (Erzgebirge, Ore Mts.). As further explained in the research design, we primarily focused on a territory and, subsequently, on the identification of relevant actor performance (including NGO representatives) within this territory, rather than on a quantitatively oriented survey among NGOs. This design enabled a comparison of different social practices in the homogeneous ecosystem present on both sides of the border and captured the influence of specific social and historical cross-border features on ENGO performance. Case study comparisons were undertaken through the Institutional Analysis and Development (IAD) framework (as developed by Ostrom 1986 and further elaborated in Polski \& Ostrom 1999 and Ostrom 2004).

In this paper, we first classify the different ENGO roles and situations as perceived in the current literature, and we stress factors that influence the efficiency and sustainability of their performance. We then introduce the research 
design and methodology regarding the development of the Czech and German case studies, which includes a description of key IAD framework outputs regarding ENGO performance and relevant factors.

\section{Framing ENGO roles and situations}

Based on the literature review, ENGOs' roles in society can be divided into five major groups (see Table 1). ENGOs defend environmental values either as watchdogs of already implemented legislation or as value perceivers challenging future policies), transfer knowledge among different actors of society and coordinate or undertake fieldwork, such as particular environmental protection projects. Furthermore, in recent decades, ENGOs have become an integral part of the collective governance of public amenities. An alternative typology of ENGOs, which is offered by Alcock (2008), is based on ideological fissures and issue orientation.

Table 1 - ENGO roles (source: authors)

\begin{tabular}{|c|c|c|}
\hline Role & Description & Authors \\
\hline ENGOs as watchdogs & $\begin{array}{l}\text { - } \text { Monitor existing environmental norm fulfilment } \\
\text { - } \text { (particularly hearings) } \\
\text { - Pursue legal action against environmentally harmful } \\
\text { projects or campaigns (in case of failures) }\end{array}$ & $\begin{array}{l}\text { Ryu et al. (2004) } \\
\text { Niedzialkowski et al. (2012a) } \\
\text { Tan (2014) }\end{array}$ \\
\hline $\begin{array}{l}\text { ENGOs as value } \\
\text { perceivers }\end{array}$ & $\begin{array}{l}\text { Promote environmental values beyond existing } \\
\text { regulations } \\
\text { - Raise citizen awareness }\end{array}$ & $\begin{array}{l}\text { Wearing et al. (2005) } \\
\text { Niedzialkowski et al. (2012b) } \\
\text { Crotty and Hall (2013) } \\
\text { Nelson (2013) }\end{array}$ \\
\hline $\begin{array}{l}\text { ENGOs as field actors and } \\
\text { action coordinators }\end{array}$ & $\begin{array}{l}\text { - Provide environmental public goods } \\
\text { - Ensure landscape maintenance } \\
\text { - Coordinate field projects in cooperation with local } \\
\text { - } \text { Undertake biodiversity/species monitoring and } \\
\text { citizen science }\end{array}$ & $\begin{array}{l}\text { Reed (1997) } \\
\text { Pasquini et al. (2011) } \\
\text { Brüntrup-Seidemann (2011) } \\
\text { Menard (2013) } \\
\text { Wende et al. (2011) }\end{array}$ \\
\hline $\begin{array}{l}\text { ENGOs as knowledge } \\
\text { transmitters }\end{array}$ & $\begin{array}{l}\text { - Educate stakeholders (including citizens) } \\
\text { - Cooperate with research organizations (e.g., within } \\
\text { the transdisciplinary research agenda) } \\
\text { - Consult land user agendas and problems }\end{array}$ & $\begin{array}{l}\text { Haigh (2006) } \\
\text { Harris and Lyon (2013) } \\
\text { Čada and Ptáčková (2013) } \\
\text { Menard (2013) }\end{array}$ \\
\hline $\begin{array}{l}\text { ENGOs as partners in } \\
\text { collaborativegovernance }\end{array}$ & $\begin{array}{l}\text { - Influence formulation and implementation of public } \\
\text { policy } \\
\text { - Consult/address environmental issues and projects } \\
\text { - Organize resource control and PES schemes }\end{array}$ & $\begin{array}{l}\text { Wende et al. (2011) } \\
\text { Leibenath }(2007,2008) \\
\text { Hrabanski et al. (2013) } \\
\text { Torfing et al. (2012) } \\
\text { Margerum (2008) } \\
\text { Wynne-Jones (2012) }\end{array}$ \\
\hline
\end{tabular}

The supposed motivation for people working in ENGOs is some form of dissatisfaction with the performance of public administration. Current trends in some countries, however, show increasing cooperation between ENGOs and states and growing (financial) support for ENGOs by states. As indicated by Reed (1997), Frazier (2006), and others, the environmental public goods provision by ENGOs is viewed as cheaper, more flexible, and transparent. On the other hand, governmental support for the whole sector brings numerous challenges for nongovernmental entities. First, access to governmental funding and the increase in influence may blunt the reformative ethos of ENGO representatives (Jepson 2005). Second, 
mandatory participation in environmental decisionmakingwithout access to additional funding may exhaust ENGO capacities (Spangenberg 2012; Cohen-Blankshtain et al. 2013). Third, even the interests of large corporate donors may shape the agenda of ENGOs, factually trapping their representatives in the dilemma between influence (and resource access) and public goal fulfilment and ethical standards (Frazier 2006). This criticism, therefore, questions the factual "independency" of influential ENGOs in representing a variety of societal interests, providing that their dominant portion of funding does not consist of numerous small private donations (which is only rarely the case) (for more discussion on this point, see Frazier 2006).

Issues of representativeness and the transparency of decision making are treated differently depending on the scale on which an organization operates. Actions of local ENGOs strongly embodied in societal structures are unanimously evaluated as positive (see Reed 1997; Brüntrup-Seidemann 2011 and Ménard 2013 for case studies). By contrast, there is a large scientific controversy regarding the interference of international ENGOs in national policy agendas and local communities. For example, Becker and Ghimire (2003) positively evaluate the effect of knowledge transfers from an international organization to the Ecuadorean forest self-management communities. This view is, however, questioned by Watson (2013), who points out the problem of the a priory superiority of (white) Western knowledge aboveindigenous knowledge. The interference of international "value perceivers" in the national political debate about hydropower development in Chile was strongly criticized by Nelson (2013).

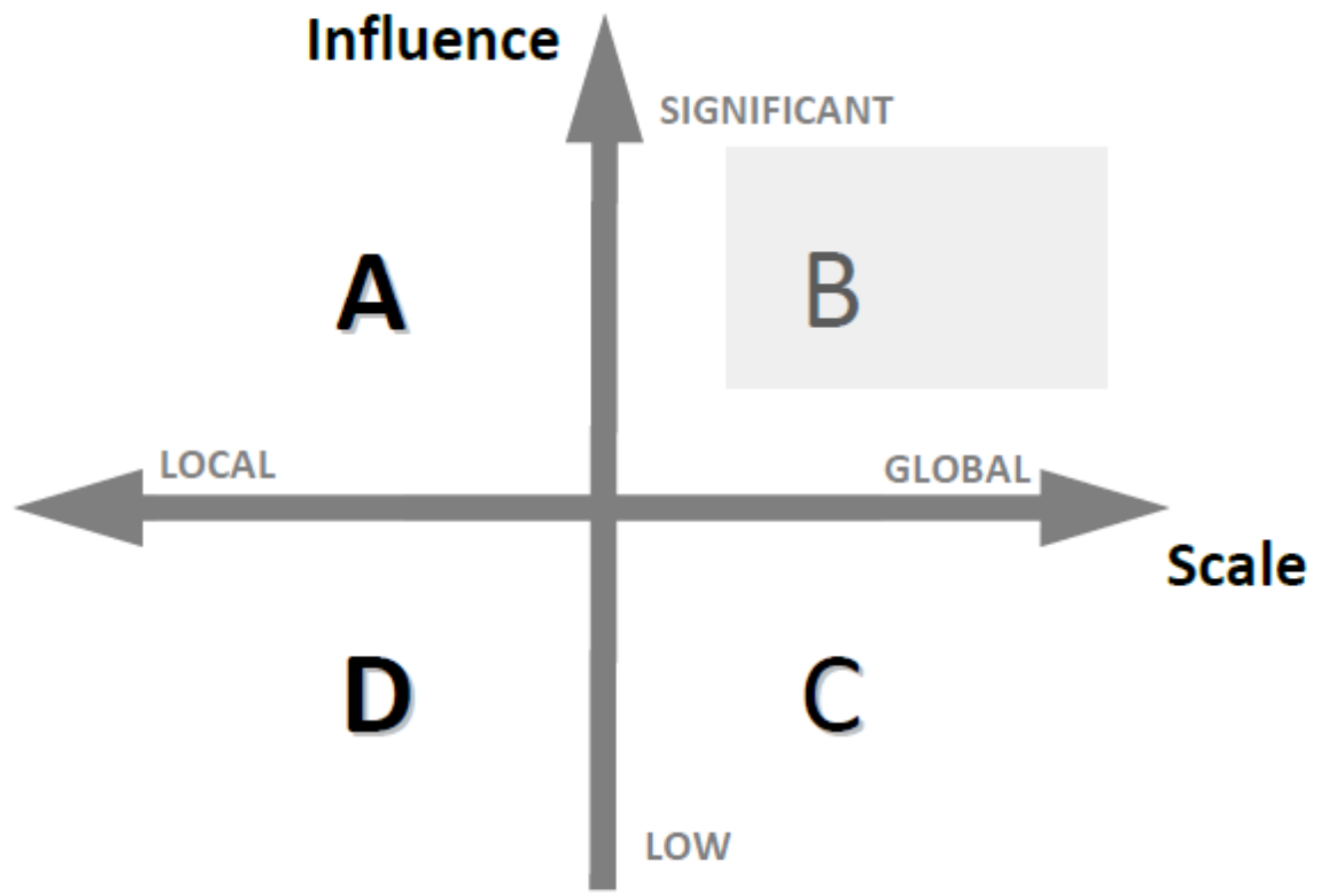

Fig. 1 - ENGO situations based on scale and influence (source: authors)

Different ENGO situations are framed in Fig. 1, where the B-section, ENGOs with high influence working on global scale, represents the most controversial research agenda discussed above. Within our research, however, we deal with entities situated in the A-section and D-section.
Specifically, we intend to reveal which factors are crucial for gaining influence at the local level. Specifically, we intend to reveal which features determine the shift from the D-section to the Asection. When dealing with these factors, 
different authors list the following as the most important:

- FINANCE: long-term sustainability of resource flows (Pasquini et al. 2011), diversity of resources (Kabdiyeva 2013), and funding partnership with public agencies (Reed 1997),

- COOPERATION: information sharing and communication strategies (Reed 1997) with other NGOs, government, businesses, and the public (Hedjazi \& Arabi 2009; Kabdiyeva 2013),

- LOCAL GROUNDING: trust and local knowledge (Ménard 2013) and peculiarities of society (Hedjazi \& Arabi 2009),

- CAPACITY MANAGEMENT: human resource management (Kabdiyeva 2013) and political, technical, and administrative skills (Balboa 2013),

- ROLES: multiple roles in society and adaptability to new agendas (Reed 1997),

- POLITICAL ENVIRONMENT: openness of the political system and the degree of political stability (O’Brian 2011).

The importance of particular factors will be discussed in the context of the field research that we present in the following chapters.

\section{Design of the field research and method}

\subsection{Methodology}

From the literature review, it is apparent that local ENGOs undertaking field actions play an important (and positively evaluated) role in environmental governance. Their role increases when there is a lack of public resources for proper ecosystem management or when certain valuable ecosystems are not subject to formal (governmental) protection.

Within our field research, we deal with the potential mismanagement of small-scale ecosystems (such as meadows and clearance cairns) in mountains. To keep these ecosystems in their proper ecological shape, regular management measures to prevent succession are required. This approach reflects the social consensus representing centuries of interactions among man and nature to protect the cultural landscape of Central Europe. As public resources designated for state nature protection tend to decrease over time, other locally grounded actions and resources must be identified, such as those associated with local ENGOs. Therefore, our intention is to determine under what circumstances these organizations serve as effective complements to state biodiversity protection within a certain territory.

When investigating roles of NGOs, a survey method that can be quantitatively evaluated is often applied (see Carmin 2003; Vaceková \& Švidroňová 2014, among others). Our focus, however, was to show the effect of contextual features such as historical development and culture on ENGO performance. When designing the research, we primarily focused on protected territory selection and, subsequently, on the identification of relevant actors, including NGO representatives. Through qualitatively oriented case studies, we were able to thoroughly analyse and compare practices across borders.

The IAD framework was applied to ensure a unified description of rules and positions of particular actors. The framework has been widely used to study complex socio-ecological situations and enables the capture of all important features and links (Ostrom 2004). The essence of this method is grounded in the detailed mapping of framework categories such as action arenas, which determine the boundaries of investigated socio-ecological systems and the situations and patterns of interaction pursued by actors. The more important part of the analysis consists of context variables such as biophysical, socioeconomical, and institutional features (see Imperial 1999 or Polski \& Ostrom 1999 for further details). The basic structure of the IAD framework has been modified and extended by numerous authors (see Clement 2010; Oakerson \& Parks 2011; Tuihedur Rahman et al. 2012); however our research was based on the original framework.

Field research was conducted in the CzechGerman border mountain region of the Krušné hory Mts. From this territory, four case study sites were selected as follows (see Fig. 2): Černá Louka (CZ-1) and Špičák (CZ-2) on the Czech side and Geisingberg (GE-3) and Gimmlitztal (GE-4) on the German side. These sites were chosen due to 
their comparable territorial units and their ability to serve as action arenas within the selected method application. Their common features are as follows:

- they are all well-depicted and subject to national nature protection (Czech natural reserves, German nature protection areas),

- they all contain a high percentage of ecologically valuable mountain meadows that need to be regularly managed to prevent succession.

Data collection was undertaken via desk studies of existing documents such as legal acts, strategies, and management plans. Numerous field visits were conducted between 2012 and 2014. An additional 18 interviews with different actors were also undertaken during this period (of which 2 were municipal representatives, 9 were ENGO representatives, 5 were state nature protectors and 2 were farmers). Interviewees were selected based on their positions in executive roles and further identified through the snow-ball sampling method (Reed et al. 2009). Interviews consisted of open-ended questions covering the following topics: the specification of positions and information particular actors had regarding the selected case sites (natural reserves), the extent to which various actors cooperated with one another, their specific roles in nature protection and regional development, and the reconciliation methods employed to resolve conflicts.

Finally, the selected key socio-ecologic features of the case studies were presented with an emphasis on the role of ENGOs as investigating actors.

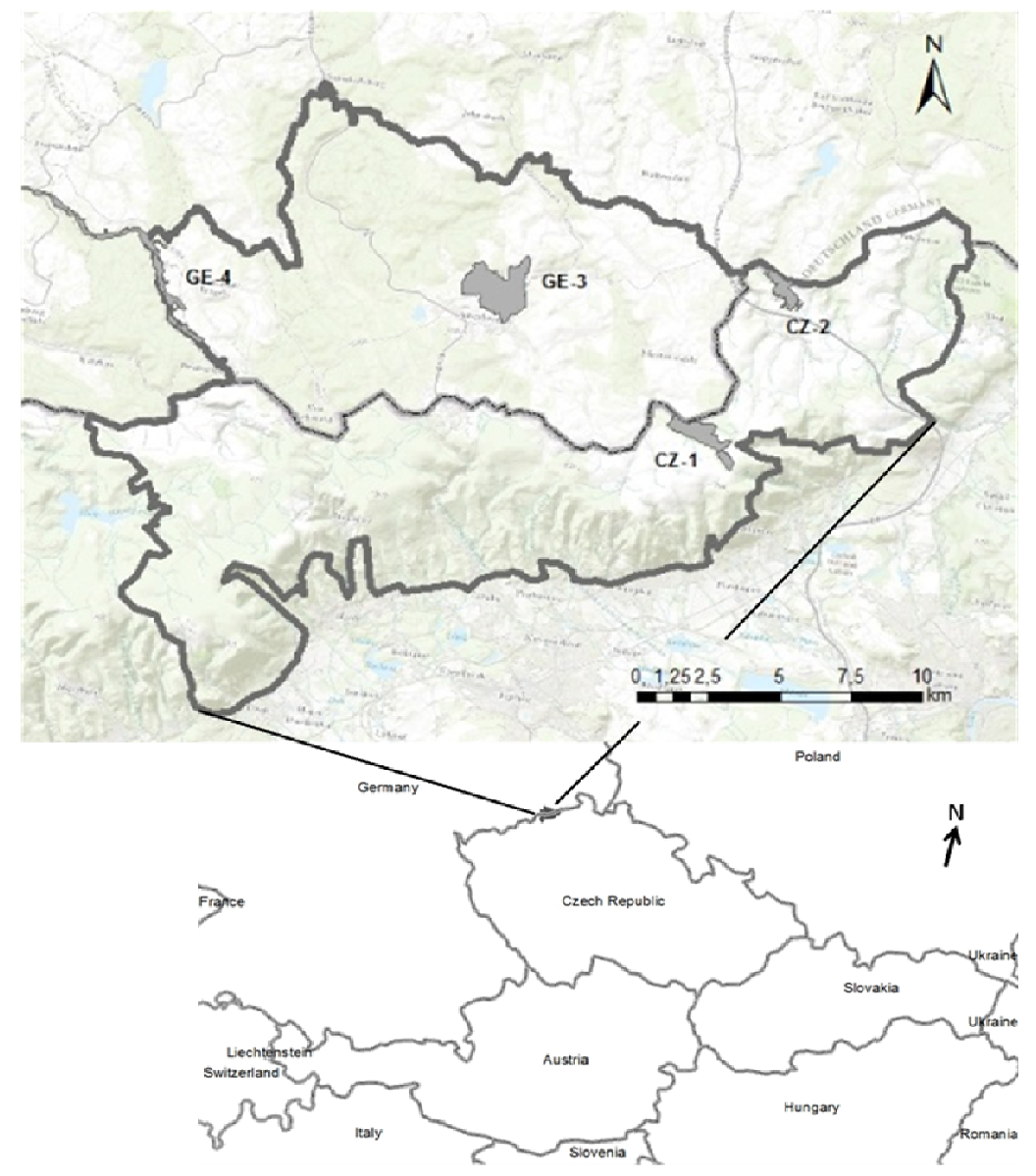

Fig. 2 - Location of the eastern the Krušné hory Mts. and selected case studies (source: authors) 


\subsection{The study area}

The study area is situated in Central Europe on the Czech-German border (see Fig. 2). The altitude varies between 350 and 850 metres above sea level, and the landscape is open with many grasslands. There are small-scale ecosystems that make the countryside ecologically and aesthetically valuable such as mountain meadows with high flora biodiversity, mountain streams, and clearance cairns (manmade stone strips). Many of these cairns are the result of historical uses of the land such as extensive pasturing or the clearance of small fields.

The territory of the eastern the Krušné hory Mts. has been settled since the 14th century as a result of mining (silver, tin and ore), and numerous mining villages used the area mainly as acre fields. During the 18th and 19th centuries, several factories were founded (toys, artificial flower production) that represented an important source of income in addition to mining. At the beginning of the 20th century, tourism started to evolve in the area. After the 2 nd World War, the Czech part of the territory was strongly affected by the collective displacement of German inhabitants, who represented a significant portion of the villagers; thus, many mountain settlements ceased to exist. The era of Communism (1948-1989) brought the intensification of agricultural practices and the abrupt development of industry in the lowlands on both sides of the border (the German side of mountains were part of "East Germany" and thus were under Soviet influence). After 1989, the fall of the Communist regime triggered an industrial (as well as economic) decline from which the area has since been slowly recovering. Currently, the territory is being used for pasturing and tourism, especially walking, cycling and skiing. The area as a whole is not subject to nature protection, but some parts belong to small-scale natural reserves and Natura 2000 sites. The unemployment rate in the area is approximately $33 \%$ higher in this area compared with national averages.

The historical evolutions of the socio-ecological interactions on the Czech and the German side of the eastern the Krušné hory Mts. show numerous common features. The main differences are summarized as follows:

1. Displacement of German inhabitants on the Czech side in 1945-46 broke the link with people in the countryside. The area is slowly being resettled, but the functioning of civil society has been affected (for more details about the settlement and land use evolution in Sudetes, see Balej et al. 2008).

2. Tourism (especially in winter) has been playing an increasingly important role on the German side throughout the 20th century. On the Czech side, the Krušné hory Mts. are not considered an appropriate place for leisure activities due to serious air pollution problems caused by the numerous industry factories in the lowlands.

3. The reunification of East and West Germany in 1990 (after the fall of Communism) brought a large amount of public resources into Germany because the protection of the cultural and environmental heritage was declared a priority.

4. Since the 1990s, the German sector part (as well as most of the former East Germany) has been affected by a declining population as many (young) people have left the area. On the other hand, towns on the Czech side are stable or slowly increasing in size.

The historical context influences nature protection activities as well as civil society performance and will be discussed further.

\section{Results}

\subsection{Characteristics of the Case Study Sites}

With respect to the IAD framework, four selected natural reserves within the eastern the Krušné hory Mts. represent action arenas for our research. Table 2 summarizes the key contextual variables of natural reserves. The German natural reserves were established during the era of Communism as a result of civil initiatives, whereas the Czech side did not become actively involved in nature reserves until 1990. In Germany, the ownership of protected land, as well as the management activities, is currently disseminated among various stakeholders, including private land owners. In the Czech 
Republic, the area is state owned, and management is, for the most part, the responsibility of private contractors and organizations.

Table 2 - Description of main characteristics of selected natural reserves (source: compiled by authors, based on natural reserve management plans)

\begin{tabular}{|c|c|c|c|c|}
\hline Case Study No. & ČernáLouka (CZ-1) & Špičák (CZ-2) & Geisingberg (GE-3) & Gimmlitztal (GE-4) \\
\hline Established in (year) & 1998 & 1997 & $\begin{array}{l}1961 \text { (extensions in } \\
1967,2000)\end{array}$ & 1974 (extension in 2015) \\
\hline Altitude (m above s. I.) & $690-760$ & $560-724$ & $545-824$ & $705-715$ \\
\hline Area (ha) & 130 & 72 & 310 since 2000 & 258 since 2015 \\
\hline $\begin{array}{l}\text { Portion of meadows } \\
(\%)\end{array}$ & $83 \%$ & $59 \%$ & $65 \%$ & $30 \%$ \\
\hline Owned by & State & State & $\begin{array}{l}\text { NGOs } \\
\text { Farmers } \\
\text { County } \\
\text { Private landowners }\end{array}$ & $\begin{array}{l}\text { State (Saxony, federal } \\
\text { gov.) } \\
\text { Private landowners }\end{array}$ \\
\hline Management & $\begin{array}{l}\text { Regional government } \\
\text { Czech Agency for } \\
\text { Nature Protection }\end{array}$ & $\begin{array}{l}\text { Regional } \\
\text { government }\end{array}$ & $\begin{array}{l}\text { NGOs } \\
\text { Farmers } \\
\text { coordinated by large } \\
\text { EU project }\end{array}$ & $\begin{array}{l}\text { Counties (partly in } \\
\text { Mittelsachsen and } \\
\text { SächsischeSchweiz- } \\
\text { Osterzgebirge) }\end{array}$ \\
\hline $\begin{array}{l}\text { Management } \\
\text { undertaken by }\end{array}$ & External contractors & $\begin{array}{l}\text { External } \\
\text { contractors }\end{array}$ & $\begin{array}{l}\text { NGOs } \\
\text { Farmers }\end{array}$ & NGO, Farmers \\
\hline
\end{tabular}

\subsection{Institutional Arrangements (Rules in Use)}

OWNERSHIP: As previously pointed out, there are differences among ownership structures. On the Czech side, there is a strong incentive to buy-out land inside small-scale natural reserves to avoid future conflicts. In Germany, some protected land is bought by the state, but interferences with other land owners are more frequent. Additionally, some protected land is bought and protected by NGOs based on private donations or EU projects.

REGULATIONS OF LAND-USE: In the Czech Republic, the regional government is responsible for the declaration of small-scale natural reserves, as well as the management and financing of these reserves. In Germany, nature protection areas are lawfully established by the state government after long negotiations among county and municipal administrations, land users, and other concerned interest groups. Some counties implement nature protection area advisors associated with ENGOs. In both countries, the use of protected areas is determined by approved management plans. These plans are regularly updated and subject to review and commentary by other stakeholders such as municipal representatives and NGOs. If there is private land within natural reserves, owners are compensated for the required management. The control of management practices is undertaken by state nature protectors. The use of land outside natural reserves is regulated through land-use plans developed by municipalities.

FINANCING: With respect to protected meadows, continuous year-to-year management is needed in order to preserve their rich biodiversity. The main issue is the cutting of grass, which sometimes cannot be performed by machinery and must be performed by hand. On the Czech side, such management is paid for by the regional office, which contracts with private firms following the principle of the lowest price bid. At Černá Louka (CZ-1), the Czech Agency for Nature 
Protection hires a local farmer to cut one part of the reserve, which is funded with money gained from the lease of another property. In Germany, money comes from various public (state, municipal) and private (donations, membership fees of NGOs) resources. Farmers living in the region are paid to undertake management activities. Furthermore, large federal projects, such as the Naturschutz-Großprojekt (at GE-3) founded by the German Nature Protection Agency, play an important role regarding management coordination. This agency also buys private land that is ecologically valuable and then transfers the land to county ownership to ensure permanent nature protection. In Germany, the funding of maintenance is primarily assumed by the EU Common Agriculture Politics (CAP - first and the second pillar), a strategy that differs from that used in the Czech Republic. In this context, it is interesting to note that the manual mowing of grass costs 625 Euro/ha in Germany compared with 890-1100 Euro/ha in the Czech Republic (2013 data). The evidence shows that commercial external service providers that regularly respond to public calls do not necessarily represent the cheapest option.

INFORMATION: The main information sources about natural reserves are publicly accessible management plans. For tourists, informational boards are placed near reserves. However, opinions differ on how and by whom the continuous marketing of the value of nature should be organized. On the German side, ENGOs play an active role as information transmitters. By contrast, the capabilities of state/regional natural protectors and politicians are strongly limited due to neo-liberal trimming of administration staff, which impacts all environmental departments at all administrative levels. On the Czech side, ENGOs are relegated to an inferior position due to their extremely limited capacities because state/regional nature protectors do not feel responsible for marketing. Thus, municipal representatives, as well as visitors to the area, know very little about the existence of natural reserves.
CONFLICTS: As there are low opportunity costs for other uses of protected areas, no severe conflicts over land-use have occurred. On the German side, negotiations with private land owners, mostly farmers, are needed to encourage these land owners to abide by management plans, but an agreement has been reached. On the Czech side, marked trails are needed to guide tourists through natural reserves. However, creating these trails is not a priority for state nature protectors. Nonetheless, tourists who visit the reserves have been tolerated as, to date, no severe damage has occurred.

\subsection{ENGO Actions}

The actors and their positions/roles are introduced in Table 3, and the strong isolation of particular actors on the Czech side is apparent. Although activities of state/regional nature protectors are to some extent supplemented by the efforts of ENGOs (and could be encouraged by local entrepreneurs) their mutual interactions are scarce. Furthermore, we focus on ENGO roles and actions within analysed action arenas.

Roles of German/Saxon ENGOs are stronger and more complex than the roles of Czech ENGOs. They are also more abundant. When searching for them, we identified three small ENGOs on the Czech side, but only one of them was still functioning as the other two dissolved when their leaders moved away. However, on the German side, based on the definition of action arena, six of the most relevant ENGOs of various types and focus were chosen.

The sole Czech organization, which comprises approximately 16 volunteers, only survived, according to the leader, due to the personal and administrative interconnections with his private environmental consulting firm. The main source of funding for this ENGO is currently represented by two EU projects focused on environmental education and the revitalization of mountain lakes. The organization has managed its own private reserve of 1.4 ha. Despite its activity in the area, it has not received much attention from state nature protectors or mayors. On the German side, numerous ENGOs of different sizes 
and focus were identified. Their activities vary from the management of natural reserves, educational activities, and large buy-out

Table 3 - Description of actor positions (source: authors) programs to the coordination of local actor networks.
Actors

Czech Side

State/Regional Nature Protectors

\section{Mayors/Municipal Representatives}

\section{ENGOs}

- protect nature, organize management of natural reserves (fear of declining public resources)

- do not support development of visitor infrastructure on reserves (tourists can go elsewhere)

- believe that available information and communication with other stakeholders is sufficient (to do more is not their job)

- promote mountains as attractive leisure-time regions

- promote development of large infrastructure projects (ski resorts) that require external funding

- have zero or limited information about existence and purpose of smallscale natural reserves in their area

- do not want to interfere with nature protectors unless necessary (general negative attitude towards reserves)

- supplement the efforts of state nature protectors in the area on small pieces of land they bought out (private reserves)

- raise money from private donors and EU grants to protect nature, but face with capacity problems (people, stable resources)

- encourage people to see value in nature (new trails, information points, etc.)

- communicate with mayors, but do not obtain support for their activities

- compete for public resources for the co-management of state natural reserves (unsuccessful thus far)

\section{German Side}

- represent the nature protection authority and coordinate nature protection

- fund landscape maintenance and nature protection measures, mainly via the EU GAP program

- assume specialized control of landscape maintenance and biodiversity success (on behalf of the EU and federal government)

- recognize basic nature protection authority is part of (municipal) county administration

- campaign for supra-regional (i.e., UNESCO) acknowledgement of large-scale areas such as "Montanregion Erzgebirge"

- see small-scale natural reserves as an opportunity for tourism development (exploit them for self-marketing)

- cooperate in nature protection activities (as land owners or donors)

- work as members in NGOs for regional tourism development, landscape maintenance and other regional purposes

- cooperate with municipalities and state nature protectors in management of protected areas, as well as environmental education and information campaigns

- buy-out large pieces of land and manage them (i.e., lend/rent to farmers or hunters but maintain control/enforce nature protection rules)

- represent, in some cases, official (legally anchored) and respected part of society

- receive different stable sources of funding (federal, state, private), fundraise EU grants

- due to large numbers of supporters/members, also use volunteers to protect nature

- diversify their activities (protection of natural and cultural heritage, etc.)

- cooperate with other ENGOs in the region 
Table 3 (continued) - Description of actor positions (source: authors)

\begin{tabular}{|c|c|c|}
\hline Actors & Czech Side & German Side \\
\hline $\begin{array}{l}\text { Local Entrepreneurs } \\
\text { (Farmers) }\end{array}$ & $\begin{array}{l}\text { - employ local people and try to attract } \\
\text { new people to revitalize mountain } \\
\text { settlements } \\
\text { - invest private resources in tourism } \\
\text { infrastructure to attract more people } \\
\text { (private ZOO, trails) } \\
\text { - promote natural reserves nearby as } \\
\text { potentially attractive landscape } \\
\text { features }\end{array}$ & $\begin{array}{l}\text { - due to land ownership, they are an integral part } \\
\text { of nature protection activities } \\
\text { - sometimes overwhelmed/confused by nature } \\
\text { protection claims from different actors } \\
\text { - tourism experts benefit from nature quality } \\
\text { realize it must be secured }\end{array}$ \\
\hline
\end{tabular}

The number of members ranges from 20 to 14,000 people, and the organizations are often supported by numerous private donors and external supporters. Annual member fees also represent an important source of funding in some of these ENGOs. An important factor is the obvious strong interconnection of ENGO sectors with other actors where one organization serves as the biodiversity management support for the state nature protection. Two other ENGOs have certified Saxony associations, thereby creating, by law, a partnership with public administration (Article 3,German Environmental Appeals Act and Article 63, Nature Protection Act).

\section{What determines success stories?}

Our intention is to explain the enormous difference between ENGO performance on the Czech side and ENGO performance on the German side of the border, considering the similarities in these socio-ecological systems (historically, culturally and socially).It is clear that Saxon ENGOs belong to the A-section (see Fig. 1) as they intentionally and self-confidently adhere to their missions at the local and national levels and function in close cooperation with other actors. On the other hand, the only Czech ENGO belongs to the $\mathrm{D}$-section and contributes to the biodiversity governance based on the abilities of its few volunteers and operates in isolation. Furthermore, we discuss the relevance of particular factors (identified in the first chapter) and reveal those features that are critical for the transformation from the D-section to the Asection.

FINANCE: The continuity of (institutional) financing represents a key issue for all ENGOs as it enables them to retain regular staff rather than just volunteers or part-time workers. Public project financing often does not enable this continuity due to time limitations or issues such as co-financing. Therefore, a sustainable strategy entails diversifying sources and developing selffinancing options over time. For example, Saxon ENGOs often assess annual member fees and recruit regular private donors, a strategy that works well, especially for large organizations with hundreds or thousands of members. Additionally, buying land and subsequently renting it to farmers (to control their practices) generates regular income for the ENGO. Equipping the organization with machinery and contracting it for regular biodiversity management represents a specific strategy employed by the German administration that is viable when continuity of policymaking is expected. On the Czech side, the limited public resources that are available for local ENGOs represent an important constraint, especially when considering that self-financing options are also underdeveloped.

COOPERATION: The Czech ENGO demonstrates a lack of willingness to cooperate with state nature protectors in the area due to differences in bureaucratic approaches to biodiversity governance. This is the primary reason ENGO members prefer managing their small private 
reserves on their own and are unwilling to declare these areas natural reserves by law. They also have not developed complex communication strategies. As volunteers, they devote their limited capacities to practical management. Additional cooperation obstacles on the Czech side are described in Table 3. On the German side, however, ENGO representatives, for the most part, express the will and the need to share with the state and the public and to gain the support of the state and the public. This strong social status makes them equal partners in negotiations with businesses. The representatives also stress the importance of networking among non-state actors, thus resulting in shared knowledge and complementarity rather than competition.

LOCAL GROUNDING: Both Czech and Saxon ENGO representatives are considered trustworthy people with deep local knowledge and grounding. However, (external) social context influences the scope of their activities. Based on our data, it is difficult to assess why Czech society in the mountain region (or perhaps as a whole) is indifferent regarding local ENGO actions. In the future, it would be valuable to explore the obvious lack of trust among local ENGOs, mayors, state nature protectors, and the public, given that this distrust results in a waste of capacities and a failure to successfully fulfil of public interests.

CAPACITY MANAGEMENT: Capacity issues are strongly determined by continuous financing. Therefore, a critical minimal flow of money is needed to ensure effective capacity management.

ROLES: Evidence derived from this study suggests that the coverage of multiple themes is an important supportive factor regarding the public influence of ENGOs. In this respect, some of the Saxon ENGOs successfully combine biodiversity protection with cultural heritage protection in areas such as the mining industry and traditional handcrafts. On the other hand, Saxon ENGOs sometimes intentionally play different roles to complement each other and fill gaps - e.g., one
ENGO may focus on field work, whereas another may focus on the coordination of local actors or campaigning.

POLITICAL ENVIRONMENT: Generally, in democratic states, ENGOs work in an environment of political stability and legal support as their actions are not prohibited, and the legal system supports non-profit entities. Still, through their statements, powerful politicians can shape public understanding of ENGO actions at the national level. In the Czech Republic, for example, a former president (Václav Klaus) has expressed strong negative attitudes towards environmental activism (calling it "ecoterrorism"). In addition to providing moral support, legislation and policymaking may strongly enhance the actions of ENGOs by assigning them formal roles in biodiversity governance (in management and negotiations).

Based on the comparison of particular factors, we determined that local grounding and field action implementation are not sufficient strategies for ENGOs to gain influence at the local level. Rather, the stability of the financing and the political support seem to play key roles. Further, the cooperation among different actors in a specific territory may create important synergies for reaching biodiversity governance goals. On the contrary, the isolation of actors results in competition between public and private entities and efforts.

Furthermore, in territories where the socioeconomic evolution has been strongly interrupted such as Sudetes) the lack of political acceptance is not compensated by civil society support of ENGOs. Such an interruption negatively involves both the number of ENGOs in the area and the number of their supporters. As emphasized by Saxon ENGO representatives, since the 19th century in Germany, there has been a long tradition of civil society associations focusing on natural and cultural heritage protection (this tradition was disrupted during the Communist era, but many associations were renewed after 1989). Interestingly on the Czech side, the absence of a vital ENGO sector does not correspond with the stated preferences of local 
inhabitants, who declare strong positive attitudes towards well-managed, small-scale ecosystems in the eastern the Krušné hory Mts. (including meadows) and are willing to contribute to the proper management of these eco-systems (see Vojáček \& Louda 2017 for more details).

\section{Conclusions}

Our research provided a unique opportunity to identify factors that determine local ENGO actions with respect to biodiversity governance within a similar socio-ecological system in two neighbouring countries, the Czech Republic and Germany. Based on the literature review, we confirmed that the field actions of local ENGOs are positively received, but their influence (and even their occurrence) may differ significantly based on available resources, public support and the continuity of the civil society evolution.

We found that ENGOs may serve as effective complements of state biodiversity protection, especially when legally anchored in governance schemes and equipped with subsequent funding. In this context, some states (including Germany) shift biodiversity management duties to the NGO sector to gain cheaper and more transparent public services. Without such support, ENGOs may be able to survive, but the extent of their activities is substantially reduced. Moreover, less they create competing independent systems of biodiversity protection.

In a united Europe within cross-boundary socioecological systems, there may be space for the evolution of transboundary ENGOs that could overcome national historical burdens and fit better with the needs of local biodiversity governance.

\section{Acknowledgements}

Firstly, the authors would like to thank Language Editing Services for English style revisions. Our research was supported by the EU INTERREG Ziel3 program. We thank the "Sächsische Aufbaubank" for funding and cooperation. Many thanks to the interviewees for their time and valuable information. Additionally, thanks to
Markus Leibenath (IÖER) for his suggestions regarding governance issues.

\section{References}

Balboa CM (2014) How Successful Transnational Nongovernmental Organizations Set Themselves up for Failure on the Ground. World Development 54: 273287. ttp://dx.doi.org/10.1016/j.worlddev.2013.09.001

Balej M, Anděl J, Raška P, Oršulák T (2008) Land use changes in northwestern part of the Czech Republic: the effects of displacement of German inhabitants. Journal of Geography and Regional Planning 1/5: 97109.

Becker CD, Ghimire K (2003) Synergy Between Traditional Ecological Knowledge and Conservation Science Supports Forest Preservation in Ecuador. Conservation Ecology $8 . \quad$ On-line: http://www.consecol.org/vol8/iss1/art1

Brüntrup-Seidemann S (2011) Actual and potential roles of local NGOs in agricultural development in subSaharan Africa. Quaterly Journal of International Agriculture 50(1): 65-78.

Čada K, Ptáčková K (2013) Possibilities and limits of collaboration between science and NGOs in the Czech Republic. Journal of Cleaner Production 49: 25-34.

Carmin J (2003) Non-governmental Organisations and Public Participation in Local Environmental Decisionmaking in the Czech Republic. Local Environment 8(5): 541-552.

Cent J, Mertens C, Niedzialkowski K (2013) Roles and impacts of non-governmental organizations in Natura 2000 implementation in Hungary and Poland. Environmental Conservation 40(2): 119-128.

Clement F (2010) Analysing decentralised natural resource governance: proposition for a "politicised" institutional analysis and development framework. Policy Sciences 43(2): 129-156.

Cohen-Blankshtain G, Ron A, Perez AG (2013) When an NGO Takes on Public Participation: Preparing a Plan for a Neighborhood in East Jerusalem. International Journal of Urban and Regional Research 37(1): 61-77.

Crotty J, Hall SM (2013) Environmental responsibility in a transition context: Russian NGO perception and response. Environmental and Planning C: Government and Policy 31(4): 667-681.

Dombrowski K (2010) Filling the gap? An analysis of non-governmental organizations responses to participation and representation deficits in global climate governance. International Environmental 
Agreements

10:

397-416.

http://dx.doi.org/10.1007/s10784-010-9140-8.

Frazier J (2006) Biosphere reserves and the "Yucatán" syndrome: another look at the role of NGOs. Landscape and Urban Planning 74: 313-333.

German Environmental Appeals Act (2003) Gesetz über ergänzende Vorschriften zu Rechtsbehelfen in Umweltangelegenheiten nach der EG-Richtlinie 2003/35/EG

Haigh MJ (2006) Promoting environmental education for sustainable development: The value of links between higher education and non-governmental organizations (NGOs). Journal of Geography in Higher Education 30(2): 327-349.

Harris F, Lyon F (2013) Transdisciplinary environmental research: building trust across professional cultures. Environmental Science and Policy 31: 109-119.

Hedjazi Y, Arabi F (2009) Factors Influencing Non Government Organizations' Participantion in Environmental Conservation. International Journal of Environmental Research 3(1): 129-136.

Hrabanski M, Bidaud C, Le Coq J-F, Méral P (2013) Environmental NGOs, policy entrepreneurs of marketbased instruments for ecosystem services? A comparison of Costa Rica, Madagascar and France. Forest Policy and Economics 37: 124-132.

Imperial MT (1999) Institutional Analysis and Ecosystem-Based Management: The Institutional Analysis and Development Framework. Environmental Management 24(4): 449-465.

Jepson P (2005) Governance and accountability of environmental NGOs. Environmental Science and Policy 8: 515-524.

Kabdiyeva A (2013) Developing Sustainable NGOs in Kazakhstan. Asian Social Science 9(7): 299-305. http://dx.doi.org/10.5539/ass.v9n7p299

Koontz TM, Newig J (2014) Cross-level Information and Influence in Mandated Participatory Planning: Alternative Pathways to Sustainable Water Management in Germany's Implementation of the EU Water Framework Directive. Land Use Policy 38: 594604.

http://dx.doi.org/10.1016/j.landusepol.2014.01.005

Leibenath M (2007) Europeanization of Cross-Border Governance? A Case-study on the Cause, Form and Consequences of a Cooperation Project in the German-Polish-Czech Border Triangle. Space \& Polity 11(2): 151-167.

Leibenath M (2008) Legitimacy of Biodiversity Policies in a Multi-level Setting. The Case of Germany. In: Keulartz J, Leistra G. (Eds.) Legitimacy in European
Nature Conservation Policy. Case Studies in Multilevel Governance. Berlin: Springer, pp. 233-250.

Mac Abbey E (2008) Constructive regulation of nongovernment organizations. The Quarterly Review of Economics and Finance 48: 370-376.

Margerum R D(2008) A Typology of Collaboration Efforts in Environmental Management. Environemental Management 41(4): 487-500.

Ménard G (2013) Environmental non-governmental organizations: key players in development in a changing climate - a case study of Mali. Environmental Development and Sustainability 15: 117-131.

Nelson M (2013) Viewpoint - Fifty years of hydroelectric development in Chile: A history of unlearned lessons. Water Alternatives 6(2): 195-206.

Newig J, Kvarda E (2012) Participation in environmental governance: legitimate and effective? In: Hogl K, Kvarda E, Nordbeck R, Pregernig M (Eds.) Environmental Governance. London: Edward Elgar, pp. 29-45.

Niedzialkowski K, Paavola J, Jedrzejewska B (2012a) Governance of biodiversity in Poland before and after the accession to the EU: the tale of two roads. Environmental Conservation 40(2): 108-118.

Niedzialkowski K, Paavola J, Jedrzejewska B (2012b) Participation and Protected Areas Governance: the Impact of Changing Influence of Local Authorities on the Conservation of the Bialowieza Primeval Forest, Poland. Ecology and Society 17(1): 2.

O'Brien T (2011) Sustaining Regional Environmental NGOs in Latin America and Eastern Europe: Considering the Experience of the FARN and the REC. Space and Polity 15(1): 49-63.

Oakerson RJ, Parks B (2011) The Study of Local Public Economies: Multi-organizational, Multi-level Institutional Analysis and Development. Policy Studies Journal 39(1): 147-167.

Ostrom E (1986) An Agenda for the Study of Institutions. Public Choice 48(1): 3-25.

Ostrom E (2004) Understanding Institutional Diversity. $\mathrm{NJ}$ : Princeton University Press.

Polski MM, Ostrom E (1999) An Institutional Framework for Policy Analysis and Design. On-line: http://mason.gmu.edu/ mpolski/documents/PolskiOs tromIAD.pdf.

Pasquini L, Fitzsimons J A, Cowell S, Brandon K, Wescott G (2011) The establishment of large private nature reserves by conservation NGOs: key factors for successful implementation. Fauna and Flora International 45(3): 373-380. 
Potluka O, Liddle J (2014) Managing European Union Structural Funds: Using a Multilevel Governance Framework to Examine the Application of the Partnership Principle at the Project Level. Regional Studies 48(8): 1434-1447.

Reed MG (1997) The Provision of Environmental Goods and Services by Local Non-governmental Organizations: an Illustration form the Squamish Forest District, Canada. Journal of Rural Studies 13(2): 177-196.

Reed MS, Graves A, Dandy N, Posthumus H, Hubacek K, Morris J, Prell Ch, Quinn C H, Stringer L C (2009) Who's in and why? A typology of stakeholder analysis methods for natural resource management. Journal of Environmental Management 90: 1933-1949.

Ryu J, Walmsley J D, Slinn P, Harashina S (2004) The role of environmental non-governmental organisations in the environmental impact assessment process in Japan. Impact Assessment and Project Appraisal 22(4): 283-293.

Spangenberg J H (2012) NGOs between influence and participation overkill: The Merits, Strenghts and Weaknesses of Environmental Civil Society Organisaitons. In: Renn O, Reichel A, Bauer J (Eds.) Civil Society for Sustainability - A Guidebook for Connecting Science and Society. Europaeischer Hochschulverlag, pp. 5-17.

Tan Y (2014) Transparency without Democracy: The Unexpected Effects of China's Environmental Disclosure Policy. Governance 27(1): 37-62

Torfing J, Peters B G, Pierre J, Sørensen E (2012 Eds.) Interactive Governance: Advancing the Paradigm. Oxford: Oxford University Press.
Tuihedur Rahman HM, Hickey GM, Sarker SK (2012) A framework for evaluating collective action and informal institutional dynamics under a resource management policy of decentralization. Ecological Economics 83: 32-41.

Vaceková G, Švidroňová M (2014) Benefits and risks of self-financing of NGOs - empirical evidence from the Czech Republic, Slovakia and Austria. Ekonomika a management 17(2): 120-130.

Valentinov V, Hielscher D, Pies I (2015) Nonprofit organizations, institutional economics, and system thinking. Economic Systems, DOI: http://dx.doi.org/10.1016/j.ecosys.2014.12.002.

Vojáček O, Louda J (2017) Economic value of ecosystem services in Eastern Ore Mountains. $E+M$, in press.

Watson A(2013) Misunderstanding the "nature" of CoManagement: A geography of regulatory science and indigenous knowledge (IK). Environmental Management 52(5): 1085-1102.

Wearing S, McDonald M, Ponting J (2005) Building a Decommodified Research Paradigm in Tourism: The Contribution of NGOs. Journal of Sustainable Tourism 13(5): 424-439.

Wende W, Kästner A, Bastian O, Walz U, Blum A, Oertel H (2011) Analyse des ehrenamtlichen und privaten Naturschutzes in Sachsen im Auftrag des Sächsischen Staatsministeriums für Umwelt und Landwirtschaft. Leibniz-Institute of Ecological Urban and Regional Development, Dresden, 255 p.

Wynne-Jones S (2012) Negotiating neoliberalism: Conservationists' role in the development of payments for ecosystem services. Geoforum 43(6): 1035-1044. 